\title{
Some Physical and Mechanical Properties of Daniellia Ogea Harms Green Timber Species
}

\author{
${ }^{1} \mathrm{JIMOH}, \mathrm{A} ;{ }^{* 2} \mathrm{CHABI}, \mathrm{AB}$ \\ Department of Civil Engineering, Faculty of Engineering and Technology \\ University of Ilorin, Ilorin Local Government, Kwara-State, Nigeria \\ *22 Corresponding Author: e-mail: arnauldmeng@gmail.com, Tel: +2347062540008 \\ ${ }^{1}$ e-mail: aajimoh4real@yahoo.com, Tel: +2347037990341
}

\begin{abstract}
Throughout the antediluvian and up to date, humans keep understanding the nature of wood which has been used to meet some bunches of human's demands such as in industry, in framing and in war. This paper presents some physical and mechanical properties of Daniellia ogea (Iya) green timber specie freshly felled from matured trees in forests around Ilorin Local Government, Kwara-State, Nigeria and cut into structural sizes within the Wood workshop of University of Ilorin premises according to BS EN 408: 2003. The moisture content and the density were the physical properties tested while the mechanical properties were the modulus of rupture and the local modulus of elasticity in bending strength, the apparent modulus of elasticity, the compressive strength perpendicular to grain then the compressive strength and tensile strength parallel to grain using the Universal Testing Machine of $300 \mathrm{kN}$ capacity of the food laboratory of the department of Agriculture of the University. Then the basic and grade stresses were determined and found to conform to the BS 5268 codes of practice. The results obtained post-tests for the moisture content and the density had respectively average values of $140.45 \%$ and $854.67 \mathrm{~kg} / \mathrm{m}^{3}$. C JASEM

https://dx.doi.org/10.4314/jasem.v21i6.18
\end{abstract}

Keywords: Timber, Apparent modulus of elasticity, Stresses, Bending, Density, Moisture content.

Over the ages, wood has emerged and expanded from an effortlessly available, simple natural to a modern industrial and engineering material which crucially contributes to human life nowadays as a vital element in the world of the forest as well as for its use as a building material (Youngs, 2001). The world has just less than 4 billion hectares of forest which cover approximately $20 \%$ of the world's land area reported by Obasi et al., (2015).

By stressing interest in local and sustainable materials such as timber, a major step is being taken towards industrialisation and economic independence by the construction industry whose primary goal is to produce a structure that combines safety, economy and aesthetic flawlessly (Aguwa, 2013). Timber machined for structural use has been for centuries used in the construction industry; nevertheless, considering several factors nowadays, the interest in structural timber has been modernized; meanwhile, green timber does not refer to the colour of the specie but the timber freshly felled from tree (Negro et al., 2013). The goal of the present research work is to investigate some physical and mechanical properties of Daniellia ogea, a genus in the subfamily of caesalpinioideae of the family fabaceae, soft and light in weight which is able to grow up to $45 \mathrm{~m}$ in height with a trunk of approximately $2-3 \mathrm{~m}$ occurring in Nigeria in old tree plantations. All the species were in structural size at their green state in view to determine the sustainable limit for their use in the construction industry. Timber for structural applications such as framing for housing requests the grading of the bending strength, the bending modulus of elasticity and the density properties obtained from laboratory experiments for unquestionable knowledge about the specie. For the need to be known and regulated to stay amidst appropriate limit and to have a common classification within the market, the grading is essentially regarded as part of a marketing approach that is designed to guarantee that buyers obtain the quality of timber suitable for their requirements and suppliers to gain an ideal price for their product (Kretschmann \& Hernandez, 2006).

This research work is expected to fulfil our understanding on Daniellia ogea timber species at green state to avoid its use in an unsuitable way which later leads to the failure of the structural members and upgrade its structural use in the construction industry by determining some physical and mechanical properties. In addition, the results obtained here will afford the grading of this timber in accordance with the green state Basic Stress in NCP 2 (1973) procedure.

\section{MATERIALS AND METHODS}

Materials sampling: Tree parts were felled by operators from the forests and transported to the six different sawmills sites where they were cut into logs form of about $1400 \mathrm{~mm}$ the same day. From each sawmill, a solid sawn wood board of $100 \times 150 \times$ $1200 \mathrm{~mm}$ were prepared still at their green state then transported to the Wood-workshop of the University of Ilorin where they were shaped in the required specimen dimensions according to the code of practice BS EN 408: 2003. A total of 60 green specimens were recovered from the specie and taken to the laboratory where they instantly subjected to the various tests.

Laboratory testing: Mechanical properties; According to the code of practice BS EN 408:2003, a total of five different types of mechanical property tests were

*2 Corresponding Author: e-mail: arnauldmeng@gmail.com 
carried out with each test loading rate determined after preliminary tests. The bending strength test, the apparent modulus of elasticity test, both the compression tests parallel and perpendicular to grain and the tensile test parallel to grain were the five tests. For the bending test, the pieces used were simply supported beams symmetrically loaded at 2 points over a span of $1000 \mathrm{~mm}$ length and at a rate of $50 \mathrm{~mm} / \mathrm{min}$ using the Universal Testing Machine of $300 \mathrm{kN}$ capacity in accordance to the apparatus and the machine. The values for the modulus of rupture and the modulus of elasticity were calculated by the machine.

For the apparent modulus of elasticity, the pieces were as well simply supported beams made of $50 \mathrm{x}$ $50 \mathrm{~mm}$ cross-section and $1000 \mathrm{~mm}$ span gauge length but loaded this time in central bending point with a constant rate of loading of $50 \mathrm{~mm} / \mathrm{min}$ so that it did not exceed the proportional limit or cause damage to the pieces using the same Universal Testing Machine of $300 \mathrm{kN}$ capacity. The values for the apparent modulus of elasticity were also calculated by the machine.

In the case of the compression tests, they were conducted using as well the Universal Testing Machine of $300 \mathrm{kN}$ capacity. The pieces were of $50 \mathrm{x}$ $50 \times 300 \mathrm{~mm}$ for the parallel to grain and $45 \times 70 \times$ $90 \mathrm{~mm}$ for the perpendicular to grain with their end surfaces particularly prepared to ensure they were plane and parallel to one another and to the loading plates then perpendicular to the axis of the piece to make sure of the accuracy of the results obtained. The load was applied in both cases at a constant rate of 50 $\mathrm{mm} / \mathrm{min}$ and concentrically.

Finally, for the tensile tests, a full structural crosssection of $650 \mathrm{~mm}$ full length, $10 \mathrm{~mm}$ thickness divided into two edges of $100 \mathrm{~mm}$ length, $50 \mathrm{~mm}$ width each and the gauge length of $450 \mathrm{~mm}$ with 5 $\mathrm{mm}$ width. The edges were scaled down to $20 \mathrm{~mm}$ length and $30 \mathrm{~mm}$ width to provide a test length clear of the testing machine grips. The tests were also conducted using the $300 \mathrm{kN}$ Universal Testing Machine and the specimens were loaded using gripping devices and the load was applied at a constant rate of $10 \mathrm{~mm} / \mathrm{min}$.

Physical properties: Firstly tested was the moisture content whose sections were cut as close as possible to the fracture right after each testing process completed and free from knots and resin pockets. In its original condition, the pieces were weighed using a digital weighing balance and disposed in the oven at a temperature of $103 \pm 2^{\circ} \mathrm{C}$ until the weights became practically constant. Then, the oven-dried weights were taken and the value of the moisture content computed using (1) below:

Moisture Content $(M C)=\frac{w w-w d}{W d} * 100$ (1)

Where, $\mathrm{W}_{\mathrm{w}}=$ Wet weight of the sample; $\mathrm{W}_{\mathrm{d}}=$ Weight of the sample after being dried at $103 \pm 2^{\circ} \mathrm{C}$.

Followed was the determination by the density which is the ratio of the mass per unit volume at a specified moisture content. The determination was conducted using the same samples used for the moisture content and the dimensions of the green specimens were taken before introducing them into the oven. The values of the density were therefore determined using (2) below:

Density $(\rho)=\frac{\text { Mass }}{\text { Voluma }}$

Where, Mass $(\mathrm{kg})$ and Volume $\left(\mathrm{m}^{3}\right)$.

Data analysis: The values recorded from the machine were adjusted to $12 \%$ moisture content using (3) then converted to $18 \%$ equivalent moisture content using (4).

$F_{12}=F w(1+\alpha(w-12))$

Where: $F_{12}=$ the ultimate strength at $12 \%$ moisture content, $\mathrm{W}=$ the moisture content at the time of testing, $\mathrm{F}_{\mathrm{w}}=$ the ultimate strength at the moisture content at the time of testing, and $\alpha=$ the correction factor for moisture content, equivalent to the percentage change in strength values for $1 \%$ change in moisture content (Table 1).

Moisture Content ${ }_{18 \%}=\frac{\$ 12 \% x 18}{12}$

Basic bending stress

$f_{\mathrm{bpar}}=\frac{f_{\mathrm{m}}-2.33 \mathrm{~g}}{2.2 \mathrm{~F}}$

Where $f_{b}$ par $=$ basic bending stress parallel to the grain

$\mathrm{f}_{\mathrm{m}}=$ mean value of the failure stresses at $18 \%$

$\sigma=$ standard deviation of the failure stresses

Basic compression stress parallel to grain

$c_{\text {b par }}=\frac{f_{\mathrm{m}}-2.330}{1.4}$

Basic compression stress perpendicular to grain

$c_{\mathrm{b} \text { perp }}=\frac{f_{\mathrm{m}}-1.96 \mathrm{~g}}{1.2}$

Basic apparent modulus of elasticity stress

$E_{N}=E_{\text {mean }}-\frac{239 \sigma}{\sqrt{N}}$

Where $E_{N}$ is the statistical minimum value of $E$ appropriate to the number of pieces $\mathrm{N}$ acting together (where $\mathrm{N}=1, \mathrm{E}_{\mathrm{N}}$ becomes the value for $\mathrm{E}_{\min }$ ) and $\sigma$ is the standard deviation. 
Basic tension stress parallel to grain

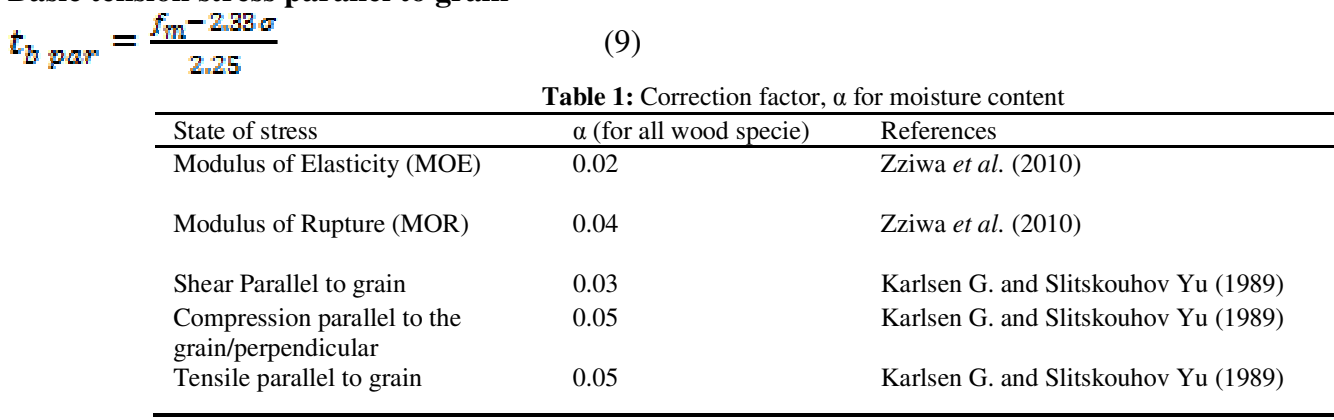

\section{RESULTS AND DISCUSSIONS}

The results for the mean failure stress values for modulus of rupture, modulus of elasticity in bending strength, apparent modulus of elasticity, compression parallel and perpendicular to grain then for tensile strength parallel to grain for the timber specie same as its adjusted characteristic values at $12 \%$ and $18 \%$ moisture content are summarized in Table 2. The basic and grade stresses also conform to the International Standards (BS 5268 codes of practice).

Table 2: Adjusted characteristic values to $12 \%$ and converted to $18 \%$ moisture content, grade and basic stresses for each of the tests

\begin{tabular}{|c|c|c|c|c|c|}
\hline & $\begin{array}{c}140.45 \% \text { moisture } \\
\text { content in laboratory } \\
\text { test }\end{array}$ & $\begin{array}{c}12 \% \text { Moisture } \\
\text { content }\end{array}$ & $\begin{array}{l}18 \% \text { Moisture } \\
\text { content }\end{array}$ & $\begin{array}{l}\text { Basic } \\
\text { stress }\end{array}$ & $\begin{array}{c}\text { Grade stress } \\
80\end{array}$ \\
\hline $\operatorname{MOR}\left(\mathrm{N} / \mathrm{mm}^{2}\right)$ & 24.24 & 148.79 & 142.97 & 11.21 & 8.97 \\
\hline Local MOE $\left(\mathrm{N} / \mathrm{mm}^{2}\right)$ & 2754.13 & 9829.49 & 9498.99 & 2498.26 & 1998.61 \\
\hline Apparent $\mathrm{MOE}\left(\mathrm{N} / \mathrm{mm}^{2}\right)$ & 52657.80 & 414.58 & 400.64 & 46531.68 & 37225.34 \\
\hline $\begin{array}{l}\text { Compression Perpendicular to } \\
\text { Grain }\left(\mathrm{N} / \mathrm{mm}^{2}\right)\end{array}$ & 12.72 & 94.41 & 90.60 & 2.98 & 2.38 \\
\hline $\begin{array}{l}\text { Compression Parallel to Grain } \\
\left(\mathrm{N} / \mathrm{mm}^{2}\right)\end{array}$ & 19.25 & 142.88 & 137.11 & 5.70 & 4.56 \\
\hline Tension Parallel to Grain $\left(\mathrm{N} / \mathrm{mm}^{2}\right)$ & 28.97 & 215.03 & 206.34 & 9.11 & 7.29 \\
\hline Shear Parallel to grain $\left(\mathrm{N} / \mathrm{mm}^{2}\right)$ & 2.23 & 10.82 & 10.42 & 0.02 & 0.02 \\
\hline
\end{tabular}

Note: $\mathrm{MOR}=$ Modulus of rupture. Local MOE = Local modulus of elasticity: Apparent MOE = Apparent modulus of elasticity

The adjustment of bending strength values to the equivalent $18 \%$ moisture content was as a result of environmental condition in Nigeria (NCP, 1972). The results show that bending strength increased as moisture contents were adjusted to $18 \%$ for the specie. It was observed that Iya (Daniellia ogea) recorded a mean strength value of $114.98 \mathrm{~N} / \mathrm{mm}^{2}$ which is greater than Kaura et al., (2015) mean value in adjusted modulus of rupture to $12 \%$ moisture content of Termilalia superba (Afara) of 83.63 $\mathrm{N} / \mathrm{mm}^{2}$. That value obtained was closer to 108 $\mathrm{N} / \mathrm{mm}^{2}$ recorded by Mohd et al., (2013) for Penaga.

For the local modulus of elasticity, the mean value at $12 \%$ moisture content recorded was 20412.23 $\mathrm{N} / \mathrm{mm}^{2}$ which, when compared to an overall mean value of $14208.21 \mathrm{~N} / \mathrm{mm}^{2}$ for Hevea brasiliensis in green condition is still higher (Nur et al., 2015). For the apparent modulus of elasticity, the mean value at $12 \%$ moisture content recorded was 187703.99 $\mathrm{N} / \mathrm{mm}^{2}$. In the case of compression parallel to grain, Iya (Daniellia ogea) recorded an overall mean value of $95.52 \mathrm{~N} / \mathrm{mm}^{2}$ in adjusted characteristic value at $12 \%$ moisture content. When compared to some other known species, Borassus aethiopum had value of $91.9 \mathrm{~N} / \mathrm{mm}^{2}$ (Asafu-Adjaye, 2012) which is closer to the recorded value. For the compression perpendicular to grain, the obtained mean value at $12 \%$ moisture content was $178.03 \mathrm{~N} / \mathrm{mm}^{2}$ which is literally higher than Borassus aethiopum (91.9 $\mathrm{N} / \mathrm{mm}^{2}$ ) obtained by Asafu-Adjaye, (2012) and by far higher than the $28 \mathrm{~N} / \mathrm{mm}^{2}$ (Antwi et al., 2014). Finally, for the tension parallel to grain, the $12 \%$ moisture content mean value obtained by Daniellia ogea was $160.73 \mathrm{~N} / \mathrm{mm}^{2}$. When compared to some known species in small clear span such as Prosopis Africana of $13.6 \mathrm{~N} / \mathrm{mm}^{2}$ (Ataguba et al., 2015) were very higher.

Grouping of this timber using green basic stresses as in NCP 2 (1973) shows that not all the green basic stresses obtained in this work fall into the same group. With the green basic stresses in Table 6 of NCP 2 (1973), the bending and tension parallel to grain basic stresses fall into group $\mathrm{N}_{5}$ and $\mathrm{N}_{6}$ respectively while the compression parallel and perpendicular to grain fall into $\mathrm{N}_{7}$ and $\mathrm{N}_{4}$ respectively. The shear parallel to grain and modulus 
of elasticity both fall below the value for the last group $\left(\mathrm{N}_{7}\right)$. If the smallest green basic stress is used to grade this timber, it means it does not fall into any green basic stress group. In any structure where the shear parallel to grain is important then the green state condition of this timber may not be usable. The mean moisture content and density obtained from (1) and (2) are summarized in Table 3 below.

Table 3: Summary of men values of moisture content of the species $(n=12)$

\begin{tabular}{|c|c|c|c|c|c|}
\hline Iya & Mean & $\begin{array}{c}\text { Mean } \\
\text { standard } \\
\text { deviation }\end{array}$ & $\begin{array}{c}\text { Coefficient of } \\
\text { variation }\end{array}$ & $95 \%$ Confidence limit & $99 \%$ Confidence limit \\
\hline Moisture content $(\%)$ & 140.45 & 39.04 & 27.80 & $116.45 \leq \mathrm{x} \leq 164.45$ & $108.45 \leq \mathrm{x} \leq 172.45$ \\
\hline Density $\left(\mathrm{kg} / \mathrm{m}^{3}\right)$ & 854.67 & 75.63 & 8.85 & $793.67 \leq \mathrm{x} \leq 915.67$ & $846.67 \leq \mathrm{x} \leq 862.67$ \\
\hline
\end{tabular}

A mean value of moisture content of $140.45 \%$ for Daniellia ogea was recorded thus, the moisture content was above the fibre saturation which confirmed the green state of the specie while concerning the density, the mean value obtained was $854.67 \mathrm{~kg} / \mathrm{m}^{3}$.

Conclusion: To evaluate the performance of Daniellia ogea and have a common classification within the market, some physical and mechanical properties tests were carried out at the green state on structural size specimens. From the results, the mean density value obtained was far higher than range of coniferous softwoods, therefore, green Daniellia ogea is classified as deciduous hardwood. Based on each of the properties, it has also been grouped according to the Nigerian code of Practice NCP2 (1973).

Acknowledgement: The authors would like to gratefully acknowledge especially family, the technologists in the carpentry workshop and the ATM laboratory of the University of Ilorin. Thank you all for your sustained support.

\section{REFERENCES}

Youngs, RL (2001). History, Nature and Products of Wood. In: Forest and Forest Plants (ed.), Vol. 2. Blacksburg, Virginia, USA. p.1-10.

Obasi, FA; Agbo, FU; Oyenekwe, CS (2015). Environmental and Socio-Economic Effects of Timbers Harvesting in Ebonyi State, Nigeria. African Journal of Agricultural Research (ed.). Academic Journals, 10(11): 1233-1238.

Aguwa, JI (2013). Structural Reliability of the Nigerian Grown Abura Timber Bridge Beam Subjected to Bending and Deflection Forces. Nigerian Journal of Technology (NIJOTECH), 32(2): 241-252.

Negro, F; Cremonini, C; Zanuttini, R (2013). CE Marking of Structural Timber: the European Standardization Framework and its Effects on Italian Manufacturers. 64(1): 55-62. Department of Agricultural, Forestry and Food Sciences (DiSAFA), University of Torino, Torino, Italy.

Nigerian Standard Code of Practice for Building and Construction, Part II, (1972). Federal Department of Forest Research, Ibadan, Nigeria. Journal of Applied Science \& Technology, 10(1 \& 2): 52 - 53.
Kretschmann, DE; Hernandez, R (2006). Grading Timber and Glued Structural Members. In: Primary Wood Processing Principles and Practice, Chapter $10,\left(2^{\text {nd }}\right.$ ed). One Gifford Pinchot Drive, Madison, Wisconsin, Dordrecht. pp. $1339-390$.

Nigerian Standard Code of Practice, NCP 2 (1973): The use of timber for construction, Nigerian Standard Organisation Federal Ministry of Industries Lagos, Nigeria.

Kaura, J; Abubakar, L; Aliyu, I; Hassan, U (2015). EN 338 Strength grade and uncertainty models of material properties for Nigerian Grown Terminalia superba( White Afara) timber specie. Nigerian Journal of Technology, 34(1): 21-27.

Mohd, JA; Mohd, ZJ; Mohamad, OM (2013). Relationship Between Mechanical Properties of Structural Size and Small Clear Specimens of Timber. (c) Forest Research Institute Malaysia. Journal of Tropical Forest Science, 25(1): $12-21$.

Nur, EAK; Gadaffi, I (2015). Strength Performance of Hevea Brasiliensis at Structural Size. Civil Engineering Department, University of Malaysia Sarawak, Kota Samarahan, Malaysia. International. Advanced research Journal in Science, Engineering and Technology (IARJSET), 2(11): 144 - 147.

Asafu-Adjaye OA (2012). Characterization of the PhysicoMechanical Properties of the Different Zones of borassus aethiopum (mmaa kube). Master's degree thesis in wood technology. College of Agriculture and Natural Resources Management, Ghana. p.1 - 244.

Antwi, K; Effah, B; Adu, G; Adu, S (2014). Strength and some Physical Properties of Allanblackia Parviflora for Furniture Production in Ghana. International Journal of Science and Technology (IJST), 4(1): $1-8$.

Ataguba, CO; Enwelu, C; Aderibigbe, W; Okiwe, EO (2015). A Comparative Study of Some Mechanical Properties of Gmelina Arborea, Parkia Biglobosa and Prosopis Africana Timbers for Structural Use. Federal Polytechnic, Idah, Nigeria. International Journal of Technical Research and Applications, 3(3): 320 - 324. 